\title{
ANTICANCER ACTIVITY OF DIPHENHYDRAMINE AGAINST PANCREATIC CANCER BY STIMULATING CELL CYCLE ARREST, APOPTOSIS, AND MODULATION OF PI3K/Akt/mTOR PATHWAY
}

\author{
RUI ZHANG ${ }^{1}$, MIN CHEN $^{2}$, LEI YU $^{1}$, ZHAOHUI JIN $^{1} *$ \\ ${ }^{I}$ Department of Pharmacy, West China Hospital, Sichuan University, 610041, Chengdu, China \\ ${ }^{2}$ Department of Gastroenterology, West China Hospital, Sichuan University, 610041, Chengdu, China \\ *corresponding author: JoansWilsonma@yahoo.com \\ Manuscript received: December 2020
}

\begin{abstract}
Each year, there is a high mortality rate due to pancreatic cancer. Thus, the current study was undertaken to evaluate the effect of diphenhydramine (DPH) against pancreatic cancer cells (PANC-1). Results suggested that DPH inhibits the proliferation of pancreatic cancer cells together with the loss of cellular morphology and induction of apoptosis in a dosedependent manner. The DPH increases the cells in the S-phase, while, few cells showed to experience apoptosis as recommended by the presence of sub-G0/G1 peak. As evidenced by Western blot, DPH causes the decline in Bcl-2 and enhancement of the Bax expression together with inhibition of PI3K/Akt/mTOR signalling cascade. DPH appears to inhibit the proliferation of pancreatic cancer cells and may prove beneficial in the management of pancreatic cancer.
\end{abstract}

\section{Rezumat}

Pornind de la rata crescută a mortalității datorată cancerului pancreatic, acest studiu a evaluat efectul difenhidraminei (DPH) asupra celulelor canceroase pancreatice (PANC-1). Rezultatele au sugerat că DPH inhibă proliferarea acestora, afectează morfologia celulară și induce apoptoza doză-dependent. DPH determină creșterea celulelor în faza S. În urma analizei Western blot, s-a observat faptul că DPH determină scăderea expresiei Bcl-2, creșterea expresiei Bax și inhibarea cascadei PI3K/Akt/mTOR. DPH a inhibat proliferarea celulelor canceroase pancreatice și poate avea un potențial efect benefic antiproliferativ în cancerul pancreatic.

Keywords: diphenhydramine, proliferation, pancreatic cancer, apoptosis, PI3K

\section{Introduction}

Among the type of cancers affecting humans, pancreatic cancer (PC) is the most devastating form of malignancy with 460,000 new cases in 2018 [1]. It is the $12^{\text {th }}$ most commonly occurring cancer in men and the $11^{\text {th }}$ most commonly occurring cancer in women. Overall, it was considered as seventh foremost cause cancer related deaths across the globe $[2,3]$. The studies indicated that developed countries are more affected by the PC than developing nations [4]. As per the estimates, alone in US, by the end of 2019, PC accounts for about $3 \%$ of all cancers and about $7 \%$ of all cancer deaths [5]. However, in past few years, the PC has spread to developing nations because of altered lifestyle and eating habits. Particularly in China, as suggested by the Chinese Cancer Registry, the fast modernization and adaption of western lifestyle has made the population more vulnerable to PC. In China, PC accounts for $19.45 \%$ of all newly diagnosed cancer and $19.27 \%$ of all deaths from pancreatic cancer worldwide [6-8]. The surgery and chemotherapy are the only viable options in the premature stage of the disease. It also provides greatest forecast for the long-term survival of the patients; however, despite this, the five-year survival rate is still low $[2,9,10]$. Therefore, new effective agents are worth to be investigated for the treatment of PC.

Diphenhydramine (DPH) is a well-known anti-histaminic agent and widely used for many pharmacological benefits, such as, anticholinergic [11], sedative, antivertigo [12], antiemetic [13], antidyskinetic [14], and local anaesthetic agent $[15,16]$. Moreover, the anticancer properties of DPH are not fully explored, except for a single study which outlines its beneficial effect against melanoma growth [17]. It has been suggested that DPH causes induction of apoptosis of melanoma cells via attenuating the STAT3/MCL-1 survival signalling. Prompted by the above, in the present study, we intended to examine the effect of DPH on the PC and to explain the mechanism behind this effect.

\section{Materials and Methods}

Cell lines and culture conditions

Pancreatic cancer cell line (PANC-1) was purchased from the American Type Culture Collection (ATCC) and sub-cultured using the standard procedure given by supplier in ambient temperature $\left(37^{\circ} \mathrm{C}\right)$, atmosphere $\left(5 \% \mathrm{CO}_{2}\right)$, and humidity $(98 \%)$. 
FARMACIA, 2021, Vol. 69, 5

Cell proliferation assay and morphological analysis The effect of DPH was assessed on the viability of PC cells by using the MTT assay. The cells were allowed to grow in well-plates at the suitable cell density per well $\left(5 \times 10^{4}\right.$ cells $)$ along with diverse concentration DPH as indicated. Next, a freshly prepared MTT solution $(20 \mu \mathrm{L}, 2.5 \mathrm{mg} / \mathrm{mL})$ was mixed in the above well-plates and then incubated for $4 \mathrm{~h}$ at $37^{\circ} \mathrm{C}$. The DMSO was further added to solubilise the Formazan crystals and the absorbance was recorded using the microplate reader at 570nm. The inverted phase contrast microscope (OLYMPUS CKX 41) was used to observe the morphological feature of cells treated with DPH at $\times 20$.

Morphological assessment of DPH on PANC-1 cells The PC cells after $48 \mathrm{~h}$ of culture were dyed with Hoechst 33258 (Beyotime, Shanghai, China) and perceived under a fluorescence microscope capable of blue filter for the evaluation of morphological transformation. The normal cell nucleus found as uniform blue, while apoptotic cells showed destructed nuclei with heavily marked pyknosis. Assay of cell apoptosis by dual staining with Annexin $V$ and propidium iodide $(P I)$
The PANC-1 cells after $48 \mathrm{~h}$ of culture were collected by centrifugation, re-suspended in binding buffer. To this, Annexin V-FITC and PI (5 $\mu \mathrm{L}$, Multi Sciences, China) was added and kept at room temperature for $15 \mathrm{~min}$. Apoptosis was evaluated by flow cytometric analysis using a FACSCanto ${ }^{\mathrm{TM}}$ II spectrophotometer (BD Biosciences, USA).

Cell cycle analysis

The trypsinization was conducted in order to collect the cells, and then treated with paraformaldehyde (4\%) for $30 \mathrm{~min}$. After washing the cells with PBS, it was centrifuged for $10 \mathrm{~min}$ and then stained with PI $(0.5 \mathrm{mg} / \mathrm{mL})$ containing RNase (BD Biosciences, NJ, USA) at $4^{\circ} \mathrm{C}$ for $30 \mathrm{~min}$. FACScan flow cytometer (BD Biosciences) was used for recording DNA content.

Wound healing assay

After $24 \mathrm{~h}$ of incubation, the monolayer of PNAC-1 confluent cells were scratched using pipette tip and then cultured in FBS-free medium with or with DPH. The average width of the wounds was determined via ImageJ software (NIH, USA) for wound closure analysis. The migration inhibitory rate was determined by the following the formula:

$$
\begin{gathered}
\text { Migration Distance }=\frac{\text { Wound width (at the begining }- \text { after the treatement })}{2} \mu m \\
\text { Migration inhibitory rate }=\frac{\text { Average migration distance }(\text { control group -treatement group })}{\text { Average migration distance of control group }} \times 100 \% \text {. }
\end{gathered}
$$

\section{Transwell assay}

The cells were treated with/without of DPH at indicated concentration for $24 \mathrm{~h}$ and the bottom chambers were added with DMEM containing $10 \%$ FBS. Using the cotton swab, the non-migrated cells were removed from the upper surface, while the migrant cells were preset $4 \%$ paraformaldehyde. The crystal violet was used for staining the cells and observed under a microscope.

Western blot analysis

The cells treated with DPH were lysed with lysis buffer. The protein concentration was determined using the Protein-assay kit (Bio-Rad Laboratories, USA) and the protein was separated by $10 \%$ SDS. It was then electroblotted on PVDF membrane with incubation with primary antibodies for overnight. The membrane was further incubated with secondary antibodies for $2 \mathrm{~h}$ and the bands were visualized using ECL and captured with Image Quant LAS 4000 (GE, USA).

Statistical analysis

All the data were expressed as mean \pm standard error (SEM). Statistical analysis was performed using oneway analysis of variance (ANOVA) followed by Bonferroni post hoc multiple comparison test using statistical software GraphPad Prism 5.0 (California, USA). The $p$ value $<0.05$ was considered as statistically significant.

\section{Results and Discussion}

Effect of DPH on cellular viability and morphology of PANC-1 cells

The effect of DPH was evaluated on the viability of human pancreatic cancer cells (PANC-1) as presented in Figure 1, via MTT assay. It has been showed that DPH causes significant loss of cellular viability at the tested dose. The most prominent effect was observed at the $10 \mu \mathrm{M}$. The effect of DPH on the cell morphology was determined using microscopic image. It has been found the DPH causes dose-dependent decline in cellular integrity of PANC-1 cells.

Effect of DPH on apoptosis of PANC-1 cells In this part, we aimed to study the effect of DPH on the apoptosis of PANC-1 cells by the fluorescence microscopic analysis. On analysing the DAPI stained cells, as shown in Figure 2A, DPH causes induction of apoptotic cells as suggested by the presence of bright blue fluorescent condensed nuclei and apoptotic bodies. Effect of DPH on the cell cycle arrest in PANC-1 cells The effect of DPH was investigated on the cell cycle phase and the results are presented in Figure 3. It has been found that, DPH showed no significant difference at the initial tested dose of $2 \mu \mathrm{M}$, as compared to control. Moreover, as the concentration of DPH increases, the numbers of cells in the S-phase were increased. Few 
FARMACIA, 2021, Vol. 69, 5

cells showed to experience apoptosis as recommended by the presence of sub-G0/G1 peak. The cell count was found to be increased in the $\mathrm{S}$-phase at the maximum tested dose of $10 \mu \mathrm{M}$ of $\mathrm{DPH}$.

A

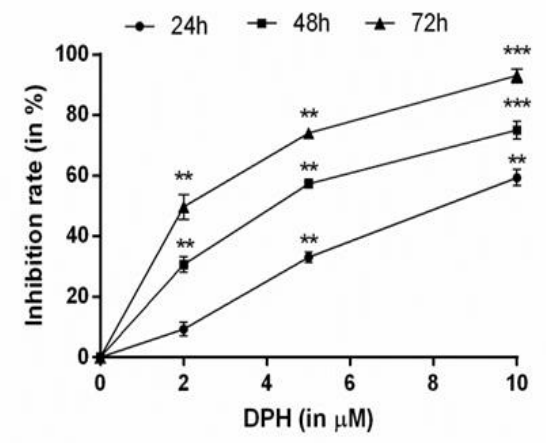

B

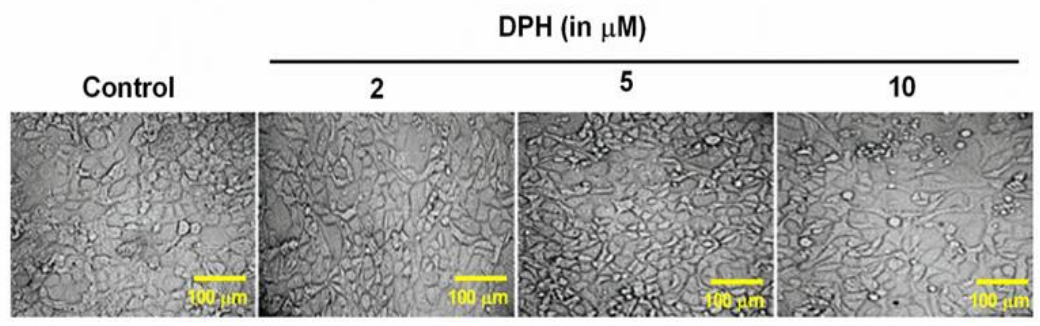

Figure 1.

Effect of DPH on (A) cellular viability on PANC-1 cells and (B) cellular integrity

Results represent means \pm SEM of three independent experiments. $* * \mathrm{p}<0.01$; *** $\mathrm{p}<0.001 \mathrm{vs}$. the control group

A Control

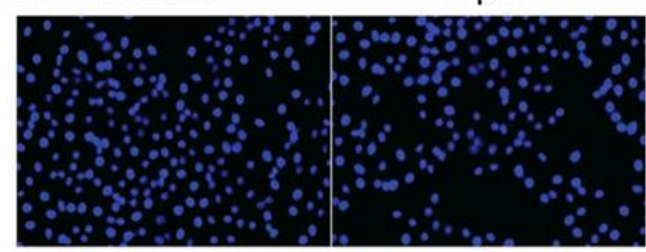

B

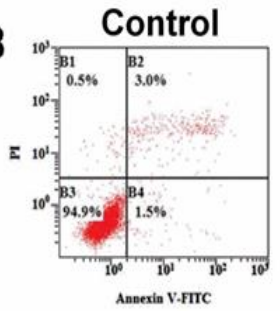

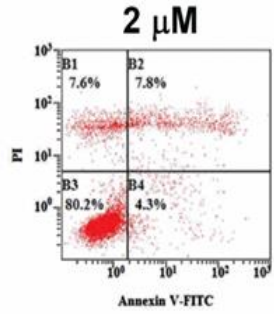

$5 \mu \mathrm{M}$
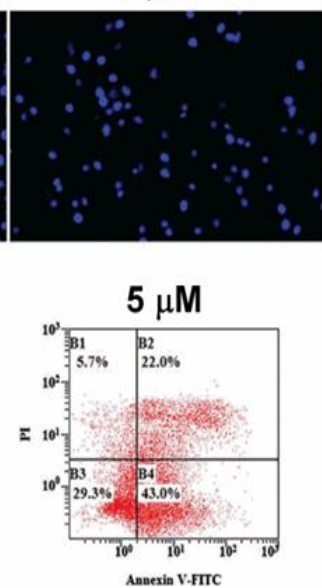

$10 \mu \mathrm{M}$
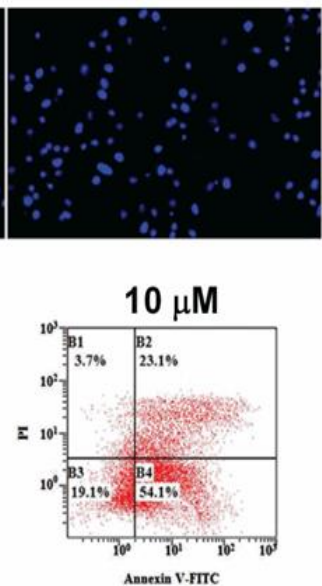

Figure 2.

Effect of DPH on the on the cellular morphology (A) and apoptosis (B) in PANC-1 cells
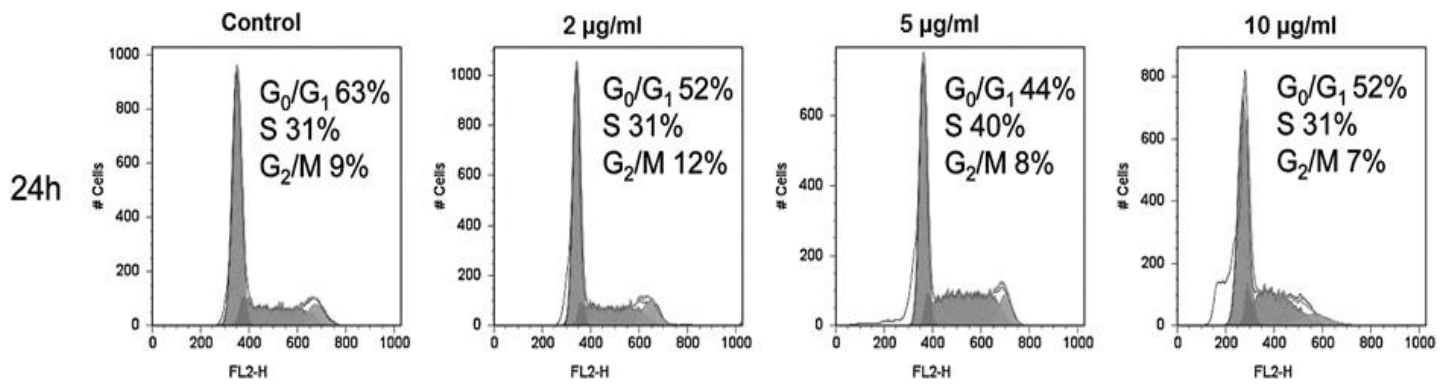

Figure 3 .

Effect of DPH on the cell phase arrest in PANC-1 cells 


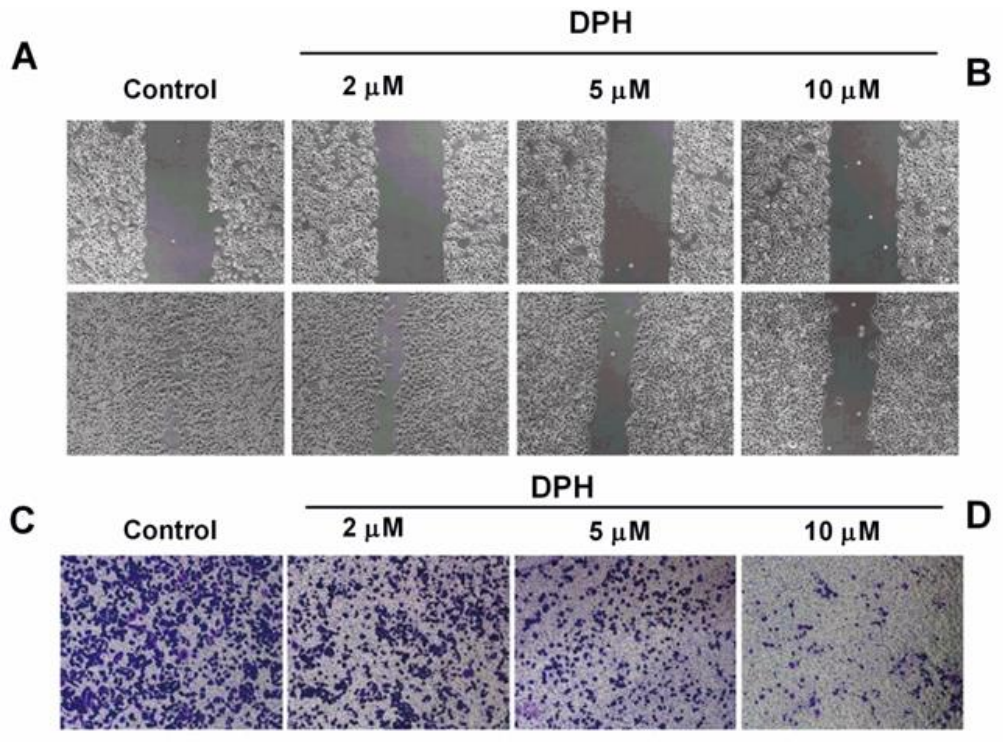

Figure 4.

Effect of DPH on the cellular migration of PANC-1 cells in wound healing assay (A and B) transwell migration assay $(\mathrm{C}$ and $\mathrm{D})$

Results represent means \pm SEM of three independent experiments. $* * p<0.01 v s$. the control group

Effect of DPH on the migration of PANC-1 cells

The next part of the study was aimed to investigate the effect of DPH on the metastasis of PANC-1 cells. For this, initially the effect of DPH was investigated on the migration of cells by the wound healing assay. In DPH treated group, the migration of the cells across the wound corner was observed be lowered as shown in Figures 4A and 4B. The transwell assay also confirmed the finding that DPH causes inhibition of pancreatic cancer cells migration (Figures 4C and 4D). These results indicated that, DPH possess the ability to attenuate the tumour metastasis.

\section{Effect of DPH on the mitochondria associated apoptotic protein}

Western blot analysis was performed to determine the effect of DPH on the expression of mitochondria associated intrinsic apoptosis protein. As shown in Figure 5, the DPH treated group showed increase in the expression of Bad and Bax, while the level of $\mathrm{Bcl} 2$ was found to be decreased significantly. The highest tested dose of DPH $(10 \mu \mathrm{M})$ causes more significant effect than other tested doses, suggesting that DPH cause dose-dependent decline of the mitochondria associated apoptotic proteins.

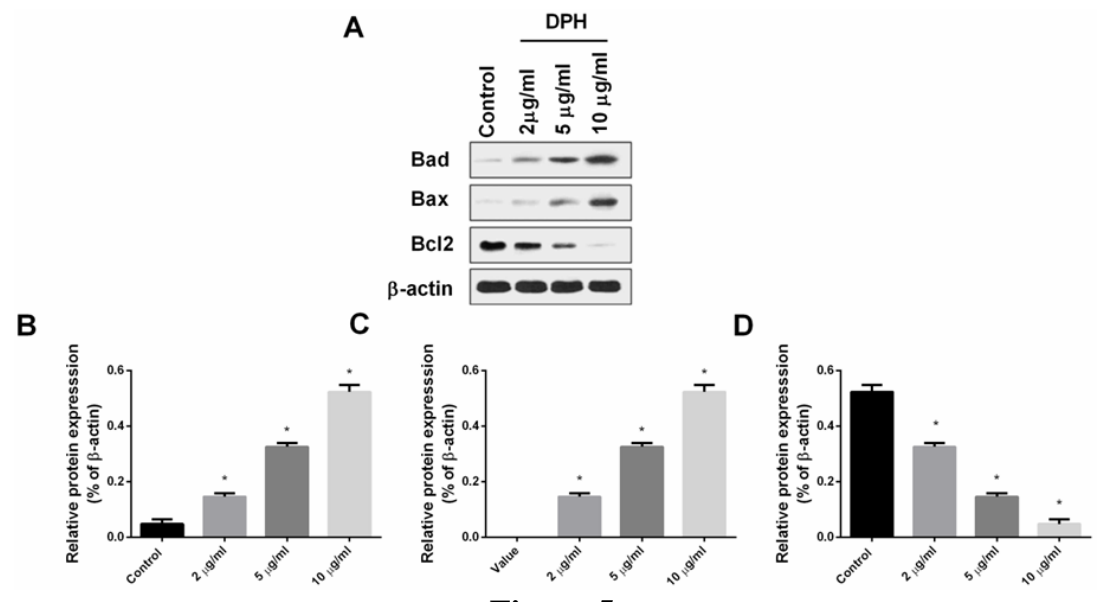

Figure 5.

Effect of DPH on the mitochondria associated apoptotic proteins as determined by Western blot (A).

Representative graph of (B) BAD, (C) Bax and (D) Bcl2

Results represent means \pm SEM of three independent experiments. $* \mathrm{p}<0.01 v s$. the control group 

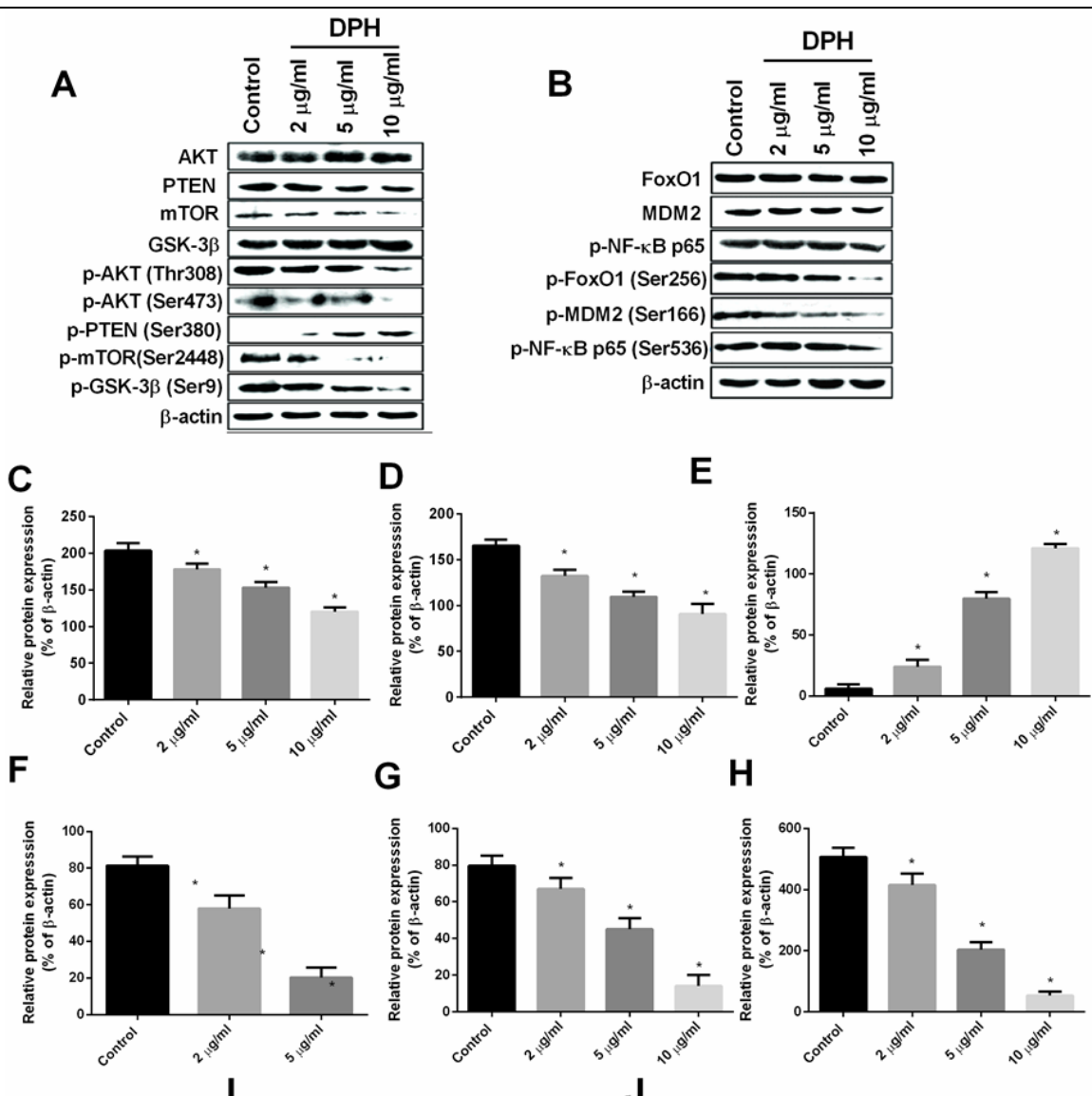

H
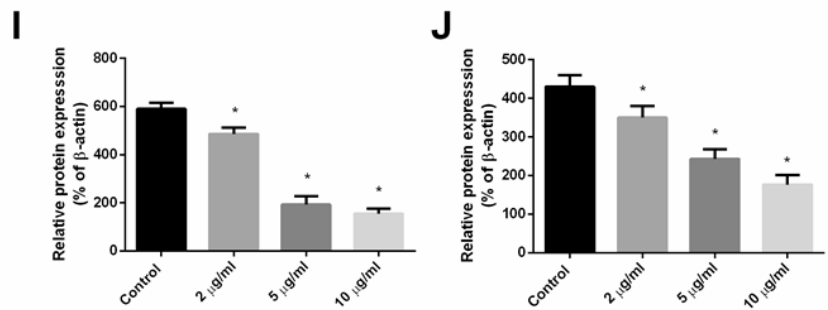

Figure 6.

DPH showed doses-dependent modulation of PI3K/Akt/mTOR patways and downstream signaling mediators in

PANC-1 cells. Where, Forkhead box protein O1 (FoxO1), (p-)FoxO1 (Ser256), Murine Double Mimute 2

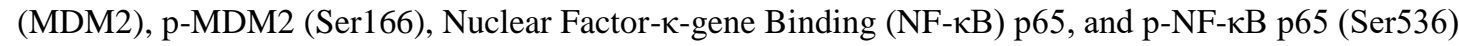

Results represent means \pm SEM of three independent experiments. ${ }^{*} \mathrm{p}<0.01 v s$. the control group

Effect of DPH on the PI3K/Akt/mTOR signalling cascade

This part of the study aimed to elucidate the effect of DPH on the PI3K/Akt/mTOR downstream signalling proteins by Western blot analysis. The results are presented in Figure 6. It has been found that, the expression of p-PTEN was found to be elevated in DPH treated group; while, the expression of p-AKT (Thr308), p-AKT (Ser 473), p-mTOR (Ser 2448), pFoxO1 (Ser 256), p-MDM2 (Ser 166), p-NF-кB p65 (Ser 536), and p-GSK-3 (Ser 9) were found to be decreased significantly in dose-dependent manner. Additionally, no significant changes were observed in the non-phosphorylated counterparts.

Pancreatic cancer is the $12^{\text {th }}$ most common form of cancer and $7^{\text {th }}$ major cause of mortality associated with cancer across globally [18]. The persons affected by the PC were expected to rise significantly in the developing nations in coming years. Despite of advances in diagnosis of cancer, it was very surprising that the cases of PC were diagnosed at the late stages $[2,10]$. The successful clinical management of PC has been also hampered due to its remote locations when surgery is not a suitable option. The fierceness of pancreatic adenocarcinoma and its resistance to chemotherapy or radiation cause difficulty in its management [19-21]. Thus, discovery of new agents that are acting via novel mechanism are fruitful option to be undertaken for the effective management of PC.

DPH is a well-known antihistamine developed in early 1940s as potent antihistaminic agent. It also possesses diverse pharmacological properties, and considered as safe drug to be sold by over the counter. This has made DPH as an attractive drug to be used in many ailments because of its safe and non-toxic profile, such as, insomnia, cough, motion sickness and itchiness 
FARMACIA, 2021, Vol. 69, 5

[22]. However the anticancer properties of the DPH have not been investigated too much till now. Few studies reported the anti-cancer potential of DPH against melanoma by in vitro and in vivo both. Recently, it has been found that, DPH causes induction of apoptosis of melanoma cell by suppressing STAT3/MCL-1 survival signalling and hinder B16-F10 melanoma growth in vivo [17].

Initially, the study was concentrated on the anticancer activity of DPH against - PANC-1 via MTT assay. It is the most significant assay to measure the effect of test drug on the viability of cells [23-25]. Results of the study suggested that DPH causes significant reduction of viability of PANC-1 cells. It also causes significant loss of cellular architecture of cancer cells as compared to untreated control. This has encouraged us to perform additional studies to assess the anticancer potential of DPH. Therefore, we further investigated the effect of DPH on the apoptosis and its marker, cell cycle arrest, and effect on PI3K/Akt/mTOR signalling pathway mediators. Apoptosis is the vital mechanism which controls the degradation of cells and recommended to be involved in many diseases, and have special importance in cancer [26, 27]. In cancer, the apoptotic pathway of the cells has been hampered due to mutations which convert normal cells to cancer cells [28, 29]. Our study indicated that, DPH causes significant induction of the apoptosis as evidenced by fluorescence microscopy of DAPI stained cells. The cell-cycle is the highly precised mechanism which governs the proliferation of cells via involvement of numerous pathways and mediators [30, 31]. Numerous studies confirmed that, in cancer, the cell cycle is aberrantly altered, thus, agents which can be able to restore this condition to normal are proved highly beneficial in controlling the cancer [32-34]. In the present study, DPH causes induction of cells in S-phase in dose-dependent manner. Moreover, some had undergone apoptosis, as suggested by occurrence of sub-G0/G1 peak. The next part of the study was conducted to elucidate the mechanism behind induction of apoptosis by DPH. Thus, we have examined the effect of DPH on the Bcl-2 family proteins, which are considered as proapoptotic and anti-apoptotic in nature governing the cellular proliferation [35-37]. It has been found that, DPH increases Bad and Bax level, while the level of $\mathrm{Bcl} 2$ was found to be decreased. These results were found in accordance with previous studies [38-40]. The effect of DPH was also investigated on PI3K/ Akt/mTOR signalling pathway. PI3K/AKT/mTOR signalling pathway considered to be as a lucrative target against cancer because of its aberrant activation in various cancers, particularly against prostate cancer [41]. It was reported to control growth, division, metabolism, and survival of cancerous cells directly or via the mTOR activation. This activation can occur via $\mathrm{SH} 2$ domains binding of $\mathrm{p} 85$ to the phospho-tyrosine residue of the activated RTKs, for instance, EGFR
[42-44]. In the present study, DPH cause inhibition of the expression of the phosphorylated proteins involved in the signalling cascade of PI3K/AKT/mTOR, revealing a possible mechanism behind DPH induced anti-pancreatic cancer effects.

\section{Conclusions}

It has been concluded that diphenhydramine cause significant reduction of prostate cancer proliferation and suggested to be mediated via induction of apoptosis and inhibition of PI3K/Akt/mTOR pathway. However, further studies are warranted to be carried out for detailed mechanism of action.

\section{Conflict of interest}

The authors declare no conflict of interest.

\section{References}

1. Rawla P, Sunkara T, Gaduputi V, Epidemiology of Pancreatic Cancer: Global Trends, Etiology and Risk Factors. World J Oncol., 2019; 10(1): 10-27.

2. Hand F, Conlon KC, Pancreatic cancer. Surgery (Oxford), 2019; 37(6): 319-326.

3. Ilic M, Ilic I, Epidemiology of pancreatic cancer. World J Gastroenterol., 2016; 22(44): 9694-9705.

4. Paulson AS, Tran Cao HS, Tempero MA, Lowy AM, Therapeutic advances in pancreatic cancer. Gastroenterology, 2013; 144(6): 1316-1326.

5. American Cancer Society: Key Statistics for Pancreatic Cancer. Am Cancer Soc., 2018; www.cancer.org/cancer/ pancreatic-cancer/about/key-statistics.html.

6. Lin QJ, Yang F, Jin C, Fu DL, Current status and progress of pancreatic cancer in China. World $J$ Gastroenterol., 2015; 21(26): 7988-8003.

7. He Y, Zheng R, Li D, Zeng H, Zhang S, Chen W, Pancreatic cancer incidence and mortality patterns in China, 2011. Chinese J Cancer Res., 2015; 27(1): 29-37.

8. Zhang Q, Zeng L, Chen Y, Lian G, Qian C, Chen S, Li J, Huang K, Pancreatic Cancer Epidemiology, Detection, and Management. Gastroenterol Res Pract., 2016; 2016: Art. ID 8962321: 1-10.

9. Anton C, Onofrei RE, Dimache M, Harja A, Malinoiu O, Hartie C, Negru D, Bulat C, Associated risk factors for pancreatic cancer: potential targets in early detection strategies. Rev Med Chir Soc Med Nat Iasi, 2019; 123(3): 384-390..

10. Freelove R, Walling AD, Pancreatic cancer: Diagnosis and management. Am Fam Physician, 2006; 73(3): 485-492.

11. Walker A, Delle Donne A, Douglas E, Spicer K, Pluim T, Novel Use of Dexmedetomidine for the Treatment of Anticholinergic Toxidrome. J Med Toxicol., 2014; 10(4): 406-410.

12. Basu R, Dodge H, Stoehr GP, Ganguli M, Sedativehypnotic use of diphenhydramine in a rural, older adult, community-based cohort: Effects on cognition. Am J Geriatr Psychiatry, 2003; 11(2): 205-213.

13. Lin TF, Yeh YC, Yen YH, Wang YP, Lin CJ, Sun WZ, Antiemetic and analgesic-sparing effects of diphenhydramine added to morphine intravenous 
patient-controlled analgesia. Br J Anaesth., 2005; 94(6): 835-839.

14. Sype JW, Khan IA, Prolonged QT interval with markedly abnormal ventricular repolarization in diphenhydramine overdose. Int J Cardiol., 2005; 99(2): 333-335.

15. Pavlidakey PG, Brodell EE, Helms SE, Diphenhydramine as an alternative local anesthetic agent. J Clin Aesthet Dermatol., 2009; 2(10): 37-40.

16. Fujita T, Ohue M, Fujii Y, Jotoku T, Miyauchi A, Takagi Y, Tsuchiya M, Endo Y, Prompt analgesic effect of antihistaminic diphenhydramine ointment on bonejoint-muscle pain as assessed by skin impedance. Pharmacology, 2013; 92(3-4): 158-166.

17. Jangi SM, Díaz-Pérez JL, Ochoa-Lizarralde B, MartínRuiz I, Asumendi A, Pérez-Yarza G, Gardeazabal J, Díaz-Ramón JL, Boyano MD, H1 histamine receptor antagonists induce genotoxic and caspase-2-dependent apoptosis in human melanoma cells. Carcinogenesis, 2006; 27(9): 1787-1796.

18. Yadav D, Lowenfels AB, The epidemiology of pancreatitis and pancreatic cancer. Gastroenterology, 2013; 144(6): 1252-1261.

19. Pai M, Spalding D, Pancreatic cancer. Medicine (UK), 2015; 43(6): 329-333.

20. Ji DL, Li CL, Cui YF, Early diagnosis of pancreatic cancer. World Chinese J Dig., 2014; 22(17): 24062413.

21. Chu LC, Goggins MG, Fishman EK, Diagnosis and detection of pancreatic cancer. Cancer J (United States), 2017; 23(6): 333-342

22. Miller SM, Cumpston KL, Diphenhydramine; in: Encyclopedia of Toxicology: $3^{\text {rd }}$ Edition. 2014; 195-197.

23. van Meerloo J, Kaspers GJL, Cloos J, Cell Sensitivity Assays: The MTT Assay. Methods Mol Biol., 2011; 731: 237-245.

24. MTT Assay; in: Encyclopedia of Cancer. 2011; 2384-2384.

25. Gerlier D, Thomasset N, Use of MTT colorimetric assay to measure cell activation. J Immunol Methods, 1986; 94(1-2): 57-63.

26. Lowe SW, Lin AW, Apoptosis in cancer. Carcinogenesis, 2000; 21(3): 485-495.

27. Mu Y, Liu Y, Hao Y, Yan L, Liang J, Dong J, Effects of ginsenoside $\operatorname{Rg} 3$ on the proliferation of glioma cells and NF-kB signalling pathway. Farmacia, 2019; 67(5): 899-904.

28. Wong RSY, Apoptosis in cancer: From pathogenesis to treatment. J Exp Clin Cancer Res., 2011; 30: Art. 87: 1-14.

29. Tan ML, Tan HK, Tengku Muhammad TS, Apoptosis and cancer; in: Cancer Immunology: A Translational Medicine Context. 2015; 209-242.

30. Kastan MB, Bartek J, Cell-cycle checkpoints and cancer. Nature, 2004; 432(7015): 316-323.
31. Williams GH, Stoeber K, The cell cycle and cancer. J Pathol., 2012; 226: 352-364.

32. Scheau C, Mihai LG, Bădărău IA, Căruntu C, Emerging applications of some important natural compounds in the field of oncology. Farmacia, 2020; 68(6): 984-991.

33. Yang VW: The Cell Cycle; in: Physiology of the Gastrointestinal Tract: $6^{\text {th }}$ Edition. 2018; 197-219.

34. Vermeulen K, Van Bockstaele DR, Berneman ZN, The cell cycle: A review of regulation, deregulation and therapeutic targets in cancer. Cell Prolif., 2003; 36(3): 131-149.

35. Adams JM, Cory S, The Bcl-2 apoptotic switch in cancer development and therapy. Oncogene, 2007; 26(9): 1324-1337.

36. Adams JM, Cory S, Bcl-2-regulated apoptosis: mechanism and therapeutic potential. Curr Opin Immunol., 2007; 19(5): 488-496.

37. Hassan M, Watari H, Abualmaaty A, Ohba Y, Sakuragi $\mathrm{N}$, Apoptosis and molecular targeting therapy in cancer. Biomed Res Int., 2014; 2014: Art. ID 150845: $1-23$.

38. Cui J, Sun R, Yu Y, Gou S, Zhao G, Wang C, Antiproliferative effect of resveratrol in pancreatic cancer cells. Phyther Res., 2010; 24: 1637-1644.

39. Arora S, Bhardwaj A, Srivastava SK, Singh S, McClellan S, Wang B, Singh AP, Honokiol arrests cell cycle, induces apoptosis, and potentiates the cytotoxic effect of gemcitabine in human pancreatic cancer cells. PLoS One, 2011; 6(6): e21573: 1-10.

40. Spampanato C, De Maria S, Sarnataro M, Giordano E, Zanfardino M, Baiano S, Cartenì M, Morelli F, Simvastatin inhibits cancer cell growth by inducing apoptosis correlated to activation of Bax and downregulation of BCL-2 gene expression. Int J Oncol., 2012; 40(4): 935-941.

41. Britten CD, PI3K and MEK inhibitor combinations: Examining the evidence in selected tumor types. Cancer Chemother Pharmacol., 2013; 71(6): 1395-1409.

42. Khan KH, Yap TA, Yan L, Cunningham D, Targeting the PI3K-AKT-mTOR singnaling network in cancer. Chin J Cancer, 2013; 32(5): 253-265.

43. Hayes TK, Neel NF, Hu C, Gautam P, Chenard M, Long B, Aziz M, Kassner M, Bryant KL, Pierobon M, Marayati R, Kher S, George SD, Xu M, WangGillam A, Samatar AA, Maitra A, Wennerberg K, Petricoin $3^{\text {rd }}$ EF, Yin HH, Nelkin B, Cox AD, Yeh JJ, Der CJ, Long-Term ERK Inhibition in KRASMutant Pancreatic Cancer Is Associated with MYC Degradation and Senescence-like Growth Suppression. Cancer Cell, 2016; 29(1): 75-89.

44. Wee P, Wang Z, Epidermal growth factor receptor cell proliferation signaling pathways. Cancers (Basel), 2017; 9(5): Art. 52: 1-45. 